\title{
RELIGION AND WEIGHT STATUS IN NIGERIA: ANALYSIS FROM THE NIGERIA DEMOGRAPHIC AND HEALTH SURVEY
}

\author{
Omololu Fagunwa
}

Federal Ministry of Health

\begin{abstract}
Obesity, the excessive accumulation of fat in the body is a global concern with major health, economic and psychosocial consequences. Nutrition and weight status are important in health and wellbeing. While the effects of undernutrition are well known and are been addressed, data are scarce on the relationship between weight status and religion in African countries. To investigate the relationship between religious affiliation and weight status in the general Nigeria population, datasets from the Nigeria Demographic and Health Surveys (NDHS) were quantitatively analysed using IBM SPSS Statistics 22. The analysis shows that religious affiliation, wealth index, age, education and residence type affect the distribution of overweight and obesity among Nigerian women age 20-49 years. Women in Southern Nigeria are more overweight and obese compared to those of the Northern region. There were more overweight and obese women among Christians (24.3\% and 10.7\%) than among adherents of other religions (14.0\% and 6.0\%) respectively. The prevalence of obesity is increasing in Nigeria. Faith leaders and faith-based organisations may be involved in the strategic plan and implementation plan on obesity and other non-communicable diseases.
\end{abstract}

KEYWORDS: Obesity, Religion, Nigeria, Africa, Nutrition, Overweight, Health Promotion, Faith-Base

\section{INTRODUCTION}

\section{Background}

Obesity, the excessive accumulation of fat in the body which leads to major health, economic and psychosocial consequences has more than doubled worldwide since 1980. Obesity, defined as the percentage of body fat and distribution, belong to the family of "complex diseases" and linked to more deaths worldwide than underweight (Bjorntorp, 2002, Lockwood, 2015, Tanija and Md, 2010, WHO, 2017). The World Health Organisation in 2014 estimated that more than 1.9 billion adults, 18 years and older, were overweight. Of these, over 600 million were obese.

Not until recent times, obesity has not been given much attention. For instance, a 1975 WHO report highlighted obesity as a potential public health problem in the United States and the United Kingdom among other developed countries but was considered irrelevant elsewhere. Medical profession disregarded obesity despite new pieces of evidence including WHO datasets around the 1980s. However, in 1995, the health organisation finds greater problems of overweight than underweight in many developing countries such as Nigeria (James, 2008). Inequalities in obesity vary by ethnic group, with children and adults from some ethnicminority groups at increased risk. For instance, Asian children are more likely to be obese than white children. In the UK, rates of adult obesity are lower in men of minor ethnicity, however, higher among black Africans, Black Caribbean, and Pakistani women (Law et al., 
2007). Cohen and Marshall (2016) while reviewing public health advocacy and redressing health inequality, documented that many of the interventions and policies expected to redress health inequities will be found outside the healthcare sector such as faith-based organizations.

Information about overweight and obesity in Nigeria is still inadequate. The Nigeria's 2013 demographic and Health Survey which was designed to provide data for monitoring the population and health situation in Nigeria did not consider overweight or obesity as a challenging health area in its report. However, within the Nigeria DHS report (2013), there are areas such as religious affiliation, that needs to be explored for better understanding of the burden of obesity in Nigeria and the associated demographic and health variables. Relationship between religion and body weight were previously examined in a national sample in the US (Kim et al., 2003), Australia (Kortt and Dollery, 2014) and the UK (Lycett, 2015). The aim of this study is to investigate the relationship between religious affiliation and weight status in the Nigerian population using secondary data analysis.

\section{Methods}

\section{Study design}

This survey was conducted by the National Population Commission (NPC) to provide population health indicators, specifically maternal and child health and family planning services at the national, zonal, state and local government levels. Hence, the standard methodologies of DHS are stated in sections for sampling, data collection, measurement variables, and data processing below.

\section{Sampling}

The sample was nationally representative covering the entire population in Nigeria. The list of enumeration areas (EAs) prepared for the 2006 population census of the Federal Republic of Nigeria was used as a sampling frame. Local government areas were divided into localities and localities subdivided into primary sampling units, otherwise called clusters. The 2013 NDHS samples were selected using a stratified three-stage cluster design consisting of 904 clusters (372 in urban and 532 in rural areas). A fixed sample take of 45 households was selected per cluster, all women aged between 15 and 49 who were either permanent residents of the households selected or visitors present in the household on the date before the survey were eligible to be interviewed. Therefore 40,680 households were invited to take part in the survey, these contained 38,948 eligible women interviewed.

\section{Data Collection}

Field staff were recruited by the National Population Commission and trained in data collection for four weeks. There were 37 interviewing teams, one for each of the 36 states of the country and the Federal Capital Territory. Each team consisted of a supervisor, a field editor, four female interviewers (for interviewing women), two male interviewers (for interviewing men; although as weight data was not collected on men they are not included in this study), and two drivers. Fieldwork was conducted from February 15, 2013, till the end of May (except for the two teams in Kano and Lagos, who completed fieldwork in June). 


\section{Measurements of Variables}

\section{Demographics}

Details of age, gender, marital status, education level, current school attendance and relationship to the head of the household was collected on each person in the selected households using the Household Questionnaire, which was available in three major Nigerian languages - Hausa, Igbo and Yoruba. The women's questionnaire collected data on literacy, religious affiliation, marital status, health insurance, media exposure, women's work and husband's background, malaria prevention and treatment, women's decision making, awareness of AIDS and other sexually transmitted infections, maternal mortality and domestic violence for all women aged between 15 and 49.

\section{Data processing}

Completed questionnaires were checked for missing data and errors, they were edited in the field immediately by the field editors. They were checked again by the supervisors before being dispatched to the data processing centre in Abuja. Data were cleaned and entered by 26 data processing personnel specially trained for this task. Data were entered using the CSPro computer package, and all data were entered twice to allow 100 per cent verification. The double entry of data enabled easy comparisons and identification of errors and inconsistencies. Secondary editing of the data was completed in the last week of July 2013. The final cleaning of the data set was carried out by the ICF data processing specialist and completed in August 2013.

\section{Eligibility criteria}

For the main analysis on the correlation between socio-demographics, spiritual affiliation and weight status, exclusion criteria were applied. Women of age 15-19years $(n=1,339)$ and pregnant women $(n=4,463)$ were excluded. Pregnancy and age under twenty will skew the measure of obesity prevalence, therefore, the data analyses included women who were not pregnant and age $20-49$ years $(n=25,680)$.

\section{Ethical Approval}

The Nigeria DHS datasets are freely available to the public at the approval of the Nigeria DHS central office, Rockville, USA. The protocol for this study was submitted, approval was granted, and the dataset downloaded via emailed online links.

\section{Weight and height}

The Household Questionnaire collected data on height and weight measurements for women age 15-49. These measures were self-reported. BMI was calculated using the formula BMI = weight $(\mathrm{kg}) /$ height $(\mathrm{m})^{2}$. BMI was categorised into the following four categories: BMI less than $18.5 \mathrm{~kg} / \mathrm{m}^{2}$ was defined as underweight, BMI ranging from 18.5 to $24.9 \mathrm{~kg} / \mathrm{m}^{2}$ was defined as a healthy weight, BMI ranging from 25.0 to $29.9 \mathrm{~kg} / \mathrm{m}^{2}$ was overweight and a BMI of $30.0 \mathrm{~kg} / \mathrm{m}^{2}$ and above as obese (WHO, 2000). 


\section{Data Analysis}

Participant characteristics were presented using descriptive statistics. The association between religion and weight status was investigated using Chi-square $\left(\mathrm{X}^{2}\right)$ test to compare and further examined using multi-nominal logistic regression. Statistical significance was set at $\mathrm{p}<0.05$ and $95 \%$ confidence interval. All analyses were performed with SPSS version 22.0 .

For the regression analysis, the following variables were recoded and transformed into two or three categories such as religion (Christian and other religions), education (no education and educated), age (younger women, 20-34 years and older women, 35-49 years), occupation (not working and working), BMI (underweight, healthy, overweight/obese).

\section{RESULTS}

\section{Characteristics of participants}

Christians (Catholic + other Christians) were $41.7 \%$, Muslims accounted for $56.8 \%$ and African traditional worshippers were $0.9 \%$ of the non-pregnant women over 19 years in the Nigeria 2013 demographic and health survey. The age was classified at 5 years' intervals and the majority of the women are between 20 - 39 years' old. Almost half of the women (45.8\%) have no formal education (Table 1).

Table 1: Sociodemographic characteristics of women respondents

\begin{tabular}{|c|c|c|c|}
\hline & Characteristics & $\mathbf{N}$ & $(\%)$ \\
\hline \multicolumn{4}{|l|}{ Religion } \\
\hline & Christianity & 10716 & 41.7 \\
\hline & Islam & 14593 & 56.8 \\
\hline & Traditional & 236 & 0.9 \\
\hline & Other & 135 & 0.5 \\
\hline & Total & 25680 & 100 \\
\hline \multirow[t]{6}{*}{ Age (years) } & $20-24$ & 5072 & 19.8 \\
\hline & $25-29$ & 7341 & 28.6 \\
\hline & $30-34$ & 5936 & 23.1 \\
\hline & $35-39$ & 4349 & 16.9 \\
\hline & $40-44$ & 2124 & 8.3 \\
\hline & $45-49$ & 858 & 3.3 \\
\hline \multirow[t]{6}{*}{ Wealth Index } & Poorest & 5544 & 21.6 \\
\hline & Poorer & 5903 & 23.0 \\
\hline & Middle & 5111 & 19.9 \\
\hline & Richer & 4806 & 18.7 \\
\hline & Richest & 4316 & 16.8 \\
\hline & Total & 25680 & 100.0 \\
\hline
\end{tabular}


African Journal of Health, Nursing and Midwifery

ISSN: 2689-9418

Volume 3, Issue 7, 2020 (pp. 111-119)

\begin{tabular}{|l|l|r|r|}
\hline Education & No education & 11753 & 45.8 \\
\hline & Primary & 5312 & 20.7 \\
\hline & Secondary & 6936 & 27.0 \\
\hline & Tertiary/Higher & 1679 & 6.5 \\
\hline & Total & $\mathbf{2 5 6 8 0}$ & $\mathbf{1 0 0 . 0}$ \\
\hline
\end{tabular}

Association between religion and weight status

Table 2: Relationship between and weight status

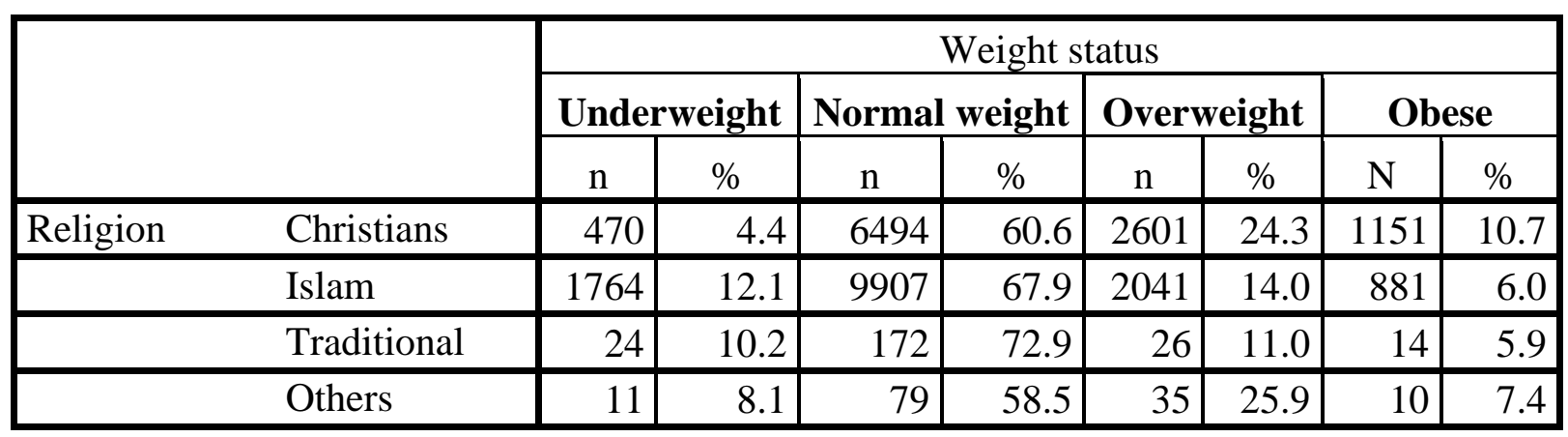

There were more overweight and obese women among Christians $(24.3 \%$ and $10.7 \%)$ than among adherents of other religions $(14.0 \%$ and $6.0 \%)$ respectively.

Table 3: Proportion of women who are overweight/obese by background characteristics of respondents $(n=25680)$

\begin{tabular}{|l|l|l|l|}
\hline & Category & $\begin{array}{l}\text { Number of } \\
\text { women }\end{array}$ & $\begin{array}{l}\text { Number and per cent of overweight } \\
\text { women within each category }\end{array}$ \\
\hline Religion & Christianity & 10716 & $3752(35.0 \%)$ \\
\hline & Islam & 14593 & $2922(20.0 \%)$ \\
\hline & $\begin{array}{l}\text { Traditional } \\
\text { Worshippers }\end{array}$ & 302 & $40(13.2 \%)$ \\
\hline & Others & 135 & $45(33.3 \%)$ \\
\hline & Total & $\mathbf{2 5 6 8 0}$ & $\mathbf{6 7 5 9}$ \\
\hline
\end{tabular}

The proportion of women with $\mathrm{BMI} \geq 25 \mathrm{gk} / \mathrm{m}^{2}$ within each category largest among Christians. 
Table 4: Simple multinomial logistics regression for the association between weight status and socio-demographic variables

\begin{tabular}{|c|c|c|c|c|c|c|c|c|c|c|c|c|}
\hline \multirow{2}{*}{ Variables } & \multicolumn{4}{|c|}{ Underweight } & \multicolumn{4}{|c|}{ Overweight } & \multicolumn{4}{|c|}{ Obese } \\
\hline & & \multicolumn{2}{|c|}{$\begin{array}{c}95 \% \\
\text { Confidence } \\
\text { interval }\end{array}$} & & & \multicolumn{2}{|c|}{$\begin{array}{l}95 \% \\
\text { Confidence } \\
\text { interval } \\
\end{array}$} & & & \multicolumn{2}{|c|}{$\begin{array}{c}95 \% \\
\text { Confidence } \\
\text { interval }\end{array}$} & \\
\hline & OR & $\begin{array}{l}\text { Lower } \\
\text { OR }\end{array}$ & $\begin{array}{l}\text { Upper } \\
\text { OR }\end{array}$ & $\begin{array}{l}\mathrm{p}- \\
\text { value }\end{array}$ & OR & $\begin{array}{l}\text { Lower } \\
\text { OR }\end{array}$ & $\begin{array}{l}\text { Upper } \\
\text { OR }\end{array}$ & $\begin{array}{l}\mathrm{p}- \\
\text { value }\end{array}$ & OR & $\begin{array}{l}\text { Lower } \\
\text { OR }\end{array}$ & $\begin{array}{l}\text { Upper } \\
\text { OR }\end{array}$ & $\begin{array}{l}\mathrm{p}- \\
\text { value }\end{array}$ \\
\hline \multicolumn{13}{|l|}{ Religion } \\
\hline Christians & 0.409 & 0.367 & 0.454 & $>0.001$ & 1.936 & 1.813 & 2.066 & $>0.001$ & 1.989 & 1.814 & 2.182 & $>0.001$ \\
\hline \multicolumn{13}{|l|}{$\begin{array}{l}\text { Others } \\
\text { (ref) }\end{array}$} \\
\hline \multicolumn{13}{|l|}{ Age } \\
\hline Younger & 1.133 & 1.022 & 1.257 & 0.018 & 0.622 & 0.580 & 0.666 & $>0.001$ & 0.494 & 0.449 & 0.543 & $>0.001$ \\
\hline \multicolumn{13}{|l|}{$\begin{array}{l}\text { Older } \\
\text { (ref) }\end{array}$} \\
\hline \multicolumn{13}{|l|}{ Education } \\
\hline \begin{tabular}{|l|} 
No \\
education
\end{tabular} & 2.054 & 1.871 & 2.254 & $>0.001$ & 0.397 & 0.370 & 0.426 & $>0.001$ & 0.325 & 0.293 & 0.361 & $>0.001$ \\
\hline \multicolumn{13}{|l|}{\begin{tabular}{|l|} 
Educated \\
(ref)
\end{tabular}} \\
\hline \multicolumn{13}{|c|}{ Occupation } \\
\hline \begin{tabular}{|l|} 
Not \\
working
\end{tabular} & 1.351 & 1.232 & 1.483 & $>0.001$ & 0.706 & 0.654 & 0.763 & $>0.001$ & 0.853 & 0.768 & 0.947 & 0.003 \\
\hline \multirow{2}{*}{\multicolumn{13}{|c|}{\begin{tabular}{|l|}
$\begin{array}{l}\text { Working } \\
\text { (ref) }\end{array}$ \\
Residence
\end{tabular}}} \\
\hline & & & & & & & & & & & & \\
\hline Urban & 0.749 & 0.676 & 0.830 & $>0.001$ & 2.183 & 2.043 & 2.333 & $>0.001$ & 2.915 & 2.656 & 3.199 & $>0.001$ \\
\hline Rural (ref) & & & & & & & & & & & & \\
\hline
\end{tabular}

a. The reference category is: normal weight.

Women whose religion is Christianity rather than those of other religions are two times more likely to be overweight $(\mathrm{OR}=1.936)$ or obese $(\mathrm{OR}=1.989)$. And they are less probable to be underweight than been normal weight $(\mathrm{OR}=0.409)$. Women who reside in urban areas rather than rural areas are two times more likely to be overweight (2.183) and three times more likely to be obese (2.915). Younger women (20-34 years) rather than older women (35-49 years) are predicted to be underweight at the same rate as those of normal weight. Also, for each unit reduction in younger women, the odds of being overweight is increased by a factor of 1.61 . The odd ratio was inverted $(1 / 0.622=1.61)$. Furthermore, for each unit reduction in younger women, the odds of being obese is increased by a factor of 2.02 . The odd ratio was inverted $(1 / 0.494=2.02)$. On occupation, women with no occupation rather than those with a defined occupation are more likely (1.4 times) to be underweight than been normal weight and for each unit reduction in the women with no education, the odds of being overweight and obese is increased by factors of 1.4 and 1.2 respectively. The odd ratios were inverted. Women with no education rather than those with formal education are two times more likely 
to be underweight as compared to being normal weight and for each unit reduction in the women with no education, the odds of being overweight and obese is increased by factors of 2.5 and 3.1 respectively. The odd ratios were inverted.

\section{DISCUSSIONS}

About $99.5 \%$ of Nigeria population is affiliated with a religion, thereby confirming the suitability of this studies (Table 1). This study also found that margin exists among the obese in urban (12.8\%) and rural (5.5\%) areas (Table 2). Overweight and obesity was found more among Christians than people of other religions and people with no religion (Table 2).

A study conducted among Christian-dominated Kalabaris in South South Nigeria reported $22.0 \%$ overweight and $49.3 \%$ obese among adult population age 20-70 years (Adienbo et al., 2012). We also found that the Christian-dominated geopolitical regions in Nigeria of South East and South South had the highest prevalence of overweight (27\% and 26.5\%) and obesity $(11.3 \%$ and $12.3 \%)$ respectively compared to the Muslim-dominated geopolitical regions of Northeast and Northwest which have a lower prevalence of overweight (13.3\% and $11.8 \%)$ and obese $(6.9 \%$ and $3.7 \%)$ respectively. North West is the stronghold of Islam in Nigeria while the South East and South South were almost totally Christians by population. Nwobodo et al. also reported a rising trend of overweight coexisting with underweight among South Easterners (Nwobodo et al., 2014). Meanwhile, studies conducted in Sokoto, a Muslimdominated North-western state observed 3.3\% overweight and $1.4 \%$ obese (Ahmad et al., 2013). This is a comparatively low prevalence and reflects the results in Tables 2 and 3. Geographical residence association with BMI also strongly validate this study hypothesis that Nigerian Christian are more likely to be overweight/obese than adherents of other religions. Ajayi et al. reported that among Christians ( $\mathrm{n}=325), 28.3 \%$ were overweight and $10.5 \%$ obese, and among Muslims ( $\mathrm{n}=67), 19.4 \%$ were overweight and $11.9 \%$ obese.

Christians are overweight and obese than adherents of other religions, even when combined. The result shown in Table 4 indicates that Christians are 2 times statistically significantly more likely to be overweight $(\mathrm{OR}=1.936$, lower $\mathrm{CI}=1.813$, upper $\mathrm{CI}=2.066 p=>0.001)$ and obese $(\mathrm{OR}=1.989$, lower $\mathrm{CI}=1.814$, upper $\mathrm{CI}=2.182 p=>0.001)$ compared to other religious affiliations than been normal weight. Table 4 also shows that Christians are less likely to be malnourished. These data are similar to previous studies. Lycett, 2015 reported that Christians (Catholic and other Christians) have higher BMI than those of other religion or those without religion of a nationally representative English population sample. That study also found a higher waist-to-hip ratio among Christian men than in other religions (Lycett, 2015). Australian studies also implicate Christians men having higher BMI than adherents of other religions. Non-Christians and other Christian women (compared to women with no religious affiliation) have lower and higher BMIs, respectively, hence the negative association between Christian religion and BMI (Kortt and Dollery, 2014). Another study in the United States found that church members are heavier than non-church members. There was a positive religious association with higher BMI in men (Kim et al., 2003). The ecumenical church has a role to play in health and healthcare including reducing the burden of overweight. Historically, Christian church is known for caring for the sick and responding to community and global health (Wilkinson, 1999). Religious or Faith-based Organizations (FBOs) have made progress with health programs such as HIV/AIDS, Malaria, Family 
planning and Polio vaccination in Africa. These organizations complement government efforts on health delivering programs. These organizations are found within the communities themselves, run by members of the community, and are trusted for health care solutions (Bandy et al. 2008). There is little engagement of FBOs in obesity reduction program in Nigeria, perhaps due to lack of data that stressed the importance among religions adherents. National health agencies should consider engaging the FBOs when developing national health plans such as those that addressed obesity.

\section{CONCLUSION}

There is need for faith-based health education and promotion. Since most Nigerians are affiliated to a religion, this makes religious setting ideal for reaching and educating the people on public health programs. Faith organisations may be major partners on the effort to reduce public health burdens and health disparities such as obesity. Non-communicable disease division of the public health department within the Nigeria ministry of health should explore potentials of faith leaders and faith-based organisations by involving them in the strategic plan and implementation plan on obesity and other non-communicable diseases.

\section{Declaration/Financial Disclosure}

There is no known conflict of interest. This project has received no finance from any organisation.

\section{REFERENCES}

Adienbo OM, Hart, VO Oyeyemi WA. High Prevalence of Obesity among Indigenous Residents of a Nigerian Ethnic Group: The Kalabaris in the Niger Delta Region of South-South Nigeria. Greener J. of Med Sci. 2012; 2(6):152-156.

Ahmad MM, Ahmed H, Airede K. Body mass index among school adolescent in Sokoto, Northwestern Nigeria. Sahel Medical Journal 2013;16(1):5-9. DOI: 10.4103/11188561.112049

Ajayi K, Alli R, Taiwo OM, Omojola ST, Oluwadare T. Prevalence of obesity among urban and rural dwellers in Nigeria. J Nutr Health Food Eng 2015;3(1): 00093.

DOI: $10.15406 /$ jnhfe.2015.03.00093

Bandy G, Crouch A, Haenni C, Holley P, Larsen CJ, Penlington S, Price N, and Wilkins C. Building from common foundations. The world health Organization and Faith-Based Organization in Primary healthcare. 2008. Available on https://apps.who.int/iris/bitstream/handle/10665/43884/9789241596626_eng.pdf

Bjorntorp P. Eating Disorders and obesity. $2^{\text {nd }}$ ed. Eds Fairburn CH, Brownell. KD. The Guildford Press, London; 2002, p.377-381

Cohen BE, Marshall SG. Does public health advocacy seek to redress health inequities? A scoping review. Health and Social Care in the Community, 2016.

DOI: $10.1111 / \mathrm{hsc} .12320$

James WPT. WHO recognition of the global obesity epidemic. International Journal of Obesity 2008;32, S120-S126. DOI: 10.1038/ijo.2008.247 
Janghorbani M, Amini M, Willet WC, Gouya MM, Delavari A, Alkhani S, Mahdavi A. First nationwide survey of prevalence of overweight, underweight, and abdominal obesity in Iranian adults. Obesity 2007;15(11): 2707-2808. DOI: 10.1038/oby.2007.332

Kandala N, Stranges S. Geographic Variation of Overweight and Obesity among Women in Nigeria: A Case for Nutritional Transition in Sub-Saharan Africa. PLoS ONE 2014;9(6):e101103. DOI: 10.1371/journal.pone.0101103

DOI: $10.1371 /$ journal.pone.0101103

Kim KH, Sobal J, Wethington E. Religion and body weight. International Journal of Obesity 2003; 27:469-477. DOI: 10.1038/sj.ijo.0802220

Kortt MA, Dollery B. Religion and BMI in Australia. J Relig Health 2014;53:217-228. DOI: 10.1007/s10943-012-9621-x

Law C, Power C, Graham H, Merrick D. Obesity and health inequalities. Obesity Reviews 2007; 8(Suppl. 1):19-22. DOI: 10.1111/j.1467-789X.2007.00312.x

Lockwood W. Obesity: Methods of Assessment. 2015 (cited 2018 Sept 21). Available on www.rn.org

Lycett D. The association between religious affiliations and body mass index (BMI): analysis from the health survey for England. J. Relig. Health 2015;54:2249-2267. DOI:

10.1007/s10943-014-9975-3

National Population Commission [Nigeria] and ICF International. Nigeria Demographic and Health Survey 2013. Rockville, Maryland, USA: National Population Commission and ICF International; 2014. Available online at https://dhsprogram.com/publications/publication-fr293-dhs-final-reports.cfm

Nwobodo ED, Anikeh LC, Obikili E, Ajeigbe K, Onwubuya EL, Ejidike H, Chukwujekwu I. Age and sex trends in the prevalence of obesity among different youth populations in South-East Nigeria. Int. J. of Public Health Epidemiol 2014;3(9):059-066.

Okoh M. Socio-demographic correlates of overweight and obesity among women of reproductive age in Nigeria. African Journal of Reproductive Health 2013; 17(4):66-76. Available online at https://www.jstor.org/stable/24362413

Tanjila TS, Md MPK. Obesity and disease association: a review. AKMMC J 2010; 1(2): 2124. DOI: https://doi.org/10.3329/akmmcj.v1i2.7461

Wilkinson J. The Bible and healing: a medical and theological commentary. The Handsel Press; Edinburg. 2008

World Health Organisation. Global Health Observatory Data Repository: Obesity (body mass index $\geq 30$ ), age-standardized (\%) Estimates by country. Geneva: WHO Press. 2017 (cited 2017 Feb 2). Available online at http://apps.who.int/gho/data/node.main.A900A?lang=en

World Health Organization. Nigeria: Country health profile. 2015 (cited 2017 Feb 2). Available online at http://www.afro.who.int/en/nigeria/country-health-profile.html.

World Health Organization. Obesity: preventing and managing the global epidemic, report of a WHO consultation (WHO Technical Report Series 894). Geneva: WHO Press; 2000. Available online at https://apps.who.int/iris/handle/10665/42330

Ziraba AK, Fotso JC, Ochako R. Overweight and obesity in urban Africa: a problem of the rich or the poor? BMC Public Health 2009;9(1):465. https://doi.org/10.1186/14712458-9-465

Copyright (C) 2020 The Author(s). This is an Open Access article distributed under the terms of Creative Commons Attribution-NonCommercial-NoDerivatives 4.0 International (CC BYNC-ND 4.0), which permits anyone to share, use, reproduce and redistribute in any medium, provided the original author and source are credited. 